Volume 3 Nomor 2, Juli-Desember 2019: hlm. 93-100.

Magister Ilmu Hukum, Fakultas Hukum, Universitas Lampung,

Bandar Lampung, Lampung, Indonesia.

E-ISSN: 2598-3105 P-ISSN: 2723-2581

http://jurnal.fh.unila.ac.id/index.php/cepalo

(c) (1) ()

\title{
IMPLIKASI DISKRESI KEPALA KANTOR PERTANAHAN DALAM PENDAFTARAN TANAH
}

\section{IMPLICATIONS OF DISCRETION IN THE HEAD OF LAND OFFICE IN LAND REGISTRATION}

\author{
Upik Hamidah \\ Universitas Lampung \\ upikhamidah21@gmail.com
}

\begin{abstract}
Abstrak
Pada keadaan tertentu menteri pertanahan serta kepala kantor pertanahan dapat mendaftarkan pemindaan hak atas tanah dalam suatu bidang tanah hak milik, yang dalam hal ini aktanya tidak dibuat oleh Penjabat Pembuat Akta Tanah atau PPAT. Hal tersebut berbanding terbalik dengan ketentuan yang terdapat dalam Pasal 37 ayat (1) PP No. 24 Tahun 1997 tentang Pendaftaran Tanah yang menentukan bahwa pemindahan hak atas suatu bidang tanah hanya dapat dilakukan apabila dapat dibuktikan dengan akta yang dibuat oleh PPAT yang berwenang menurut ketentuan peraturan perundang-undangan yang berlaku. Permasalahan yang akan dibahas dalam penelitian ini adalah bagaimana implikasi hukum dari kebijakan kepala kantor pertanahan dalam pendaftaran tanah? Penelitian ini menggunakan metode hukum normatif, dengan pendekatan peraturan perundang-undangan dan bahan pustaka lainnya.

Berdasarkan hasil penelitian bahwa kebijakan mendaftarkan pemindahan hak milik atas sebidang tanah yang dilakukan oleh kepala kantor pertanahan bertentangan dengan ketentuan yang ada dalam Pasal 37 PP No. 24 Tahun 1997 tentang Pendaftaran Tanah, sehingga pemindahan hak atas sebidang tanah yang dilakukan tidak sah menurut hukum. Implikasi berlaku sepanjang kepala kantor pertanahan dengan terangterangan mendaftarkan hak milik atas sebidang tanah di daerah perkotaan, sehingga dapat dipastikan tidak termasuk kategori daerah terpencil sebagaimana di maksud dalam ketentuan Pasal 37 PP No. 24 Tahun 1997. Dengan demikian, perlu dilakukan perubahan isi dalam Pasal 37 PP No. 24 Tahun 1997, mengenai pengaturan dalam keadaan tertentu. Akan lebih baik jika keadaan tertantu yang dimaksud diperinci dalam batang tubuh sehingga tidak menimbulkan multi interprestasi yang dapat menjadi celah penyalahgunaan wewenang sehingga berpotensi merugikan masyarakat.
\end{abstract}

Kata Kunci: Implikasi Hukum, Kebijakan, Pendaftaran Tanah.

\section{Abstract}

In certain circumstances, the minister of land and the head of the land office can register the scavenging of land rights in a parcel of land, which in this case the act was not done by the Land Deed Making Officer or PPAT. It is inversely proportional to the provisions contained in Article 37 paragraph (1) Government Regulation or PP No. 24 of 1997 concerning Land Registration which stipulates that the transfer of title to a parcel of land can only be done if it can be proven by a deed made by the authorized PPAT according to the provisions of the prevailing laws and regulations. The problem that will be discussed in this research is how the legal implications of the policy of the head of the land office in land registration? This study uses a normative legal method, with the approach to the legislation and other literature.

Based on the results of research that the policy of registering the transfer of ownership of a parcel of land carried out by the head of the land office is contrary to the provisions contained in Article 37 PP No. 24 of 1997 concerning Land Registration, so the transfer of rights to a parcel of land carried out is not legal according to law. The implication applies as long as the head of the land office explicitly registers the ownership rights to a parcel of land in an urban area, so it can be ascertained not to be categorised as a remote area as intended under Article 37 PP No. 24 of 1997. Thus, the content needs to be changed in Article 37 PP No. 24 of 1997, concerning regulation in certain circumstances. It would be better if the situation in question is specified in the torso so as not to cause multi-interpretation which can be a gap of abuse of authority so that it has the potential to harm the community. 
Keywords: Legal Implications, Policy, Land Registration.

Cara Mengutip (How to Cite): Upik Hamidah, "Implikasi Diskresi Kepala Kantor Pertanahan Dalam Pendaftaran Tanah”, Jurnal Cepalo, 3 (2), (2019): 93-100.

DOI: https://doi.org/10.25041/cepalo.v3no2.1849

\section{A. Pendahuluan}

Tanah merupakan karunia Tuhan Yang Maha Esa yang diberikan kepada manusia untuk keberlangsungan hidup. Tanah adalah salah satu sumber daya alam yang mempunyai peran yang sangat penting dalam keberlangsungan hidup manusia dan mahluk lainnya. Dengan demikian tanah harus dikelola dan diberdayagunakan sebagaimana mestinya agar dapat memberikan manfaat yang besar untuk kesejahteraan dan kemamkuran masyarakat. ${ }^{1}$ Tanah yang dikaruniakan Tuhan kepada manusia untuk dipergunakan dengan baik dan semaksimal mungkin tanpa harus merusak alam sekitar. Kerusakan lingkungan dan punahnya berbagai macam mahluk ciptakaan Tuhan lainnya dikarenakan ulah manusia itu sendiri.

Setiap tanah yang dimiliki oleh setiap masyarakat atau penduduk wajib hukumnya memperoleh kepastian hak atas milik dalam sebidang tanah yang dimilikinya. Hal ini agar kepastian hukum dan legalitas tanah yang dimilik oleh masyarakat secara resmi dapat dilindungi hukum secara pasti. Hak milik atas tanah dapat berubah karena perlakuan dari setiap masyarakat seperti menjualnya, sehingga tanah tersebut menjadi hak milik orang lain. Atas dasar kepemilikan yang resmi dalam hak atas tanah diperlukan pendaftaran tanah agar mempunyai kekuatan milik di mata hukum.

Penyelenggara Pendafataran Tanah adalah tugas dari Negara yang dilakukan serta dilaksanakan oleh pemerintah untuk kepentingan rakyat, dalam hal ini tujuannya adalah untuk memberikan kepastian hukum dibidang pertanahan. Dalam pelaksanaan pendaftaran tanah, yang mempunyai wewenang untuk melakukan kegiatan tersebut adalah Kantor pertanahan, dalam pelaksanaanya Kantor Pertanahan dibantu oleh Pejabat Pembuat Akta Tanah (PPAT) yang berada disetiap Kabupaten/Kota. Sebagian program pemerintah terkait kebijaksanaan pertanahan dilakukan penerbitan sertifikat hak-hak atas tanah seperti Hak Milik, Hak Guna Bangunan, Hak Guna Usaha Hak pakai dan Hak Sewa.

Hak milik merupakan salah satu jenis dari hak atas tanah, oleh karenanya hak milik adalah kedudukannya lebih tinggi diantara hak atas tanah yang lainnya. Menurut Hermi hak milik mempunyai harga atau nilai yang paling tinggi dibandingkan dengan dengan hak atas tanah yang lainnya dengan bidang tanah yang sama kualitasnya dan bentuknya sehingga hak milik tidak dibatasi masa berlakunya oleh negara. ${ }^{2} \mathrm{Hak}$ milik pada dasarnya merupakan hak tertinggi dari segala hak dalam bidang tanah, hal ini dikarenakan hak milik adalah hak yang melekat secara ilmiah dan alami dari keturunan atau pemilik hak atas tanah. Akan tetapi dalam membuktikan hak milik tanah tersebut harus mempunyai bukti yaitu berupa sertifikat hak milik, namun sebelum itu untuk mendapatkan sertifikat hak milik tanah juga harus dilakukan pendaftaran terlebih dahulu agar tidak menimbulkan permasalahan yang akan merugikan salah satu pihak.

Peralihan hak atas tanah dalam ketentuan peraturan perundang-undangan pendaftaran tanah yang berlaku wajib untuk dilaksanakan (didaftarkan) di kantor pertanahan pada tataran pelaksanaan kemungkinan besar menimbulkan kondisi tertentu yang berbeda dalam pengaturannya. Oleh karena itu kepemilikan atas tanah dapat dibuktikan dengan menunjukan sertifikat hak atas tanah yang dikelurkan atau diterbitkan oleh Badan Kantor Pertanahan Nasional (BPN) memungkinkan beralih dan dialihkan kepada pihak lain, hal ini disebakan karena adanya indikasi permainan dari eksternal yang menimbulkan penayalahgunaan wewenang dan akan merugikan kepentingan dari setiap individu.

Salah satu contoh yang dapat dijadikan sebagai alur fikir adalah dalam suatu keadaan tertentu sebagaimana ditentukan oleh menteri, kepala kantor pertanahan dapat melakukan atau mendaftar pemindahan hak atas suatu bidang tanah hak milik yang aktanya tidak dibuat oleh PPAT. Hal ini berbanding terbalik yang ada dalam Pasal 37 ayat (1) PP. No 24 Taun 1997 yang menyatakan bahwa pemindahan hak

\footnotetext{
${ }^{1}$ Ana Silviana, “Kajian Tentang Kesadaran Hukum Dalam Melaksanakan Pendaftaran Tanah”, Pandecta, Vol. 7 No. 1, (2012), hlm. 113.

${ }^{2}$ Hekan Hermit, Cara Memperoleh Sertifikat Tanah ak Milik, Tanah Negara, dan Tanah Pemda, Teori Praktek Pendaftaran Tanah Di Indonesia, Bandung: Mandar Maju, (2004), hlm.2.
} 
atas tanah suatu bidang tanah hak milik hanya dapat dilakukan (didaftarkan) apabila dapat membuktikan akta hak milik yang dibuat oleh PPAT yang berwenang menurut ketentuan peraturan perundang-undangan yang berlaku. Oleh karenanya dalam peralihan hak atas tanah hak milik sering terjadi, hal ini yang akan menjadi pemabahasan dalam penelitian ini.

Berdasarkan hal tersebut, maka penulis tertarik untuk melakukan penelitian terkait "Implikasi Diskresi Kepala Kantor Pertanahan Dalam Pendaftaran Tanah". Permasalahan dalam Penelitian ini adalah bagaimana analisis implikasi hukum dari kebijakan kepala kantor pertanahan dalam pendaftaran tanah dengan terlebih dahulu melakukan pemetaan mengenai pengaturan tentang pendaftaran tanah dalam peraturan perundangundangan yang berlaku saat ini. Metode yang digunakan dalam penelitian adalah metode penelitian hukum normatif, dengan menggunakan pendekatan peraturan perundang-undangan yang terakit dengan pertanahan. ${ }^{3}$ Selanjutnya disusun dengan menggunakan kata dan bahasa yang mudah dimengerti dan dapat dipertangungjawabkan secara hukum.

\section{B. Pembahasan}

Cadaster merupakan istilah dari pendaftaran pertanahan yang didalamnya memuat record (rekaman, menunjukan kepada luas, nilai serta kepemilikan lain atas hak) terhadap suatu bidang tanah. Capistrum berasal dari bahasa latin yang berarti capita yang diperbuat untuk pajak tanah pada zaman Romawi. ${ }^{4}$ Dalam kaitannya dengan tanah yang akan diperoleh hak miliknya, tanah harus mempunyai kekuatan dan landasan hukum yang kuat yang dapat dipertanggungjawabkan secara pasti dan tidak melanggar peraturan yang ada. Pendaftaran Tanah sebagaimana dimaksud dalam Pasal 1 ayat (1) PP.No.24 Tahun 1997 tentang Pendaftaran Tanah menentukan bahwa, pendaftaran tanah adalah serangkaian kegiatan yang dilakukan oleh Pemerintah secara terus menerus berkesinambungan, dan teratur meliputi pengumpulan, pengolahan, pembukuan, dan penyajian serta pemeliharaan data fisik data yuridis dalam bentuk peta dan daftar mengenai bidang-bidang tanah dan satuan-satuan rumah susun, termasuk pemberian surat tanda bukti hanya bagi bidang tanah yang sudah ada haknya dan hak milik atas satuan rumah susun, serta hak-hak tertentu yang membidanginya.

Pendaftaran tanah merupakan salah satu upaya pemerintah dalam memberikan jaminan kepastian hukum terhadap hak milik atas tanah, hal ini terdapat dalam Pasal 19 UUPA. ${ }^{5}$ Dengan demikian peran pemerintah dalam menjamin kepastian hukum terhadap masyarakat agar tidak terjadi sengketa dan perselisihan yang disebabkan oleh tanah akan berkurang. Namun pada kenyataanya dalam praktek dilapangan masih banyaknya tanah yang belum miliki sertifikat yang dengan alasan masyarakat tidak mengetahui bagaimana memperoleh sertifikat tersebut. Selanjutnya dalam pelaksanaan pendaftaran tanah dan peralihan hak milik atas bidang tanah merupakan kewenangan dari instansi terkait yang sudah mendapatkan amanah. Kenyataanya dalam melaksanakan kewenangan masih banyak penyelewengan yang dilakukan sehingga dalam memahami definisi yang ada dan berarti ganda dalam peraturan dimanfaatkan oleh oknum-oknum tertentu yang akan merusak citra dan keharmonisasian peraturan perundang-undangan yang ada. Wewenang yang diberikan kepada kepala kantor pertanahan baik kabupaten/kota sering menimbulkan permasalahan baru, hal ini disebabkan kepala kantor pertanahan selalu mengartikan suatu peraturan dengan niat untuk mencari kesempatan dalam suatu keterbukaan.

\section{Pengaturan Pendaftaran Tanah dalam Peraturan Perundang-Undangan yang Berlaku di Indonesia.}

Pemerintah dalam menjamin kepastian hukum di bidang pertanahan selanjutnya dilakukan suatu kegiatan pendaftaran tanah, mengeluarkan peraturan perundang-undangan yang mengatur semua hal yang berkaitan dengan pendaftaran tanah. Walaupun pendaftaran tanah belum maksimal, ${ }^{6}$ pembaruan sistem hukum mengenai aturan yang tegas terus berlangsung. Secara filosofi, landasan mengenai penguasaan atas tanah sepenuhnya diberikan kepada negara atau dengan kata lain bahwa, bumi dan air dan kekayaan alam yang terkandung didalamnya dikuasasi oleh negara. Hal ini dijelaskan oleh Pasal 33 ayat (3) UndangUndang 1945 yang mengatakan bahwa: "Bumi dan air dan kekayan alam yang terkandung didalamnya dikuasai oleh Negara dan dipergunakan sebesar-besarnya untuk kemakmuran rakyat. Namun dalam

\footnotetext{
${ }^{3}$ Peter Mahmud Marzuki, Penelitian Hukum, Jakarta: Kencana, (2013).

${ }^{4}$ A. P. Perlindungan. Pendaftaran dan Konversi Hak-Hak Atas Tanah Menurut UUPA, Bandung: Alumni, (1985), hlm. 2.

${ }^{5}$ Harris Yonata, "Parmahan Sibuea, Arti Penting Pendaftaran Tanah Untuk Pertama Kali, Negara Hukum", Vol. 2 No. 2, (2011), hlm. 289.

${ }^{6}$ Elita Rahmi, "Eksistensi Hak Pengelolaan Atas Tanah (HPL) dan Realitas Pembangunan Indonesia”, Dinamika Hukum, Vol. 10 No. 3, (2010), hlm. 349.
} 
kenyataan pada saat ini bahwa negara dan penguasa berdiri secara bersama dan menekan rakyat, sehingga ketentuan yang ada dalam pasal tersebut hanyalah simbol kepentingan diatas kepentingan. Selanjutnya Pemerintah dalam memperbaiki dan penataan terhadap peraturan dan memberikan payung hukum yang memperkuat tanah sebagai berikut:

a. Undang-Undang Republik Indonesia Nomor 5 Tahun 1960 tentang Peraturan Dasar Pokok-Pokok Agraria;

b. Peraturan Pemerintah Republik Indonesia Nomor 24 Tahun 1997 tentang Pendaftaran Tanah;

c. Peraturan Menteri Negara Agraria/Kepala Badan Pertanahan Nasional Nomor 3 Tahun 1997 tentang Ketentuan Pelaksanan Peraturan Pemerintah Nomor 24 Tahun 1997 tentang Pendaftaran Tanah;

d. Peraturan Kepala Badan Pertanahan Nansional Nomor 8 Tahun 2012 tentang Perubahan Atas Peratutan Menteri Negara Agraria/Kepala Badan Peratanahn Nasional Nomor 3 Tahun 1997 tentanag Ketentuan Pelaksanaan Peraturan Pemerintah Nomor 24 Tahun 1997 tentang Pendaftaran Tanah.

Ketentuan yang tedapat dalam peraturan perundang-undangan tentang agraria yang selama ini ketentuan yang bersifat umum, dalam hal ini Undang-Undang Nomor 5 Taun 1960 tentang Peraturan Dasar Pokok-Pokok Agraria (UUPA), yang mengatur tentang pendaftaran tanah. Ketentuan mengenai pendaftaran tanah ini kemudian perlu dilakukan atau dibentuknya suatu peraturan pelaksana yang bersifat lebih komprehensif,aArtinya peraturan pelaksana yang lebih menjelaskan secara rinci mengenai isi pasal dan rincian substansi yang ada dalam setiap pasal tersebut. Oleh karenanya, menindak lanjuti hal tersebut dibuatlah suatu produk hukum pemerintah yang dijadikan dasar pelaksana mengenai pendaftaran tanah. Dengan berlakunya peraturan pemerintah tersebut diharapkan akan membuat suatu perubahan yang penting dalam permasalahan yang dihadapan bangsa Indonesia yaitu mengenai masalah pertanahan yang begitu penting dalam kehidupan dalam masyarakat, baik masyarakat desa maupun masyarakat yang tinggal di sebuah kota yang berkembang.

Namun dalam perkembangannya, PP No. 10 Tahun 1961, pendaftaran tanah diselenggarakan oleh Jawatan Penadaftaran Tanah yang dalam hal ini ditetapakan oleh Meteri Agraria pada masing-masing daerah. Pasal 1 dan Pasal 2 dalam PP No. 10 Tahun 1961 itu menyatakan bahwa pendaftaran tanah diselenggarakan di desa-desa atau daerah-daerah yang setingkat dengan itu. Dapat dikatakan, dalam peraturan ini tidak relevan dengan semangat pembaharuan, sehingga diperlukan adanya payung hukum tentang pendaftaran tanah yang bertujuan untuk meningkatkan kekuatan dan keamanan dalam pendaftaran tanah, maka dibuatlah peraturan pemerintah yang baru. Sehingga diharapakan dapat membuat suatu kebijakan dan penetapan baru dalam pendaftaran tanah yang lebih baik lagi yaitu PP No. 24 Tahun 1997 tentang Pendaftaran Tanah.

Ada beberapa hal yang baru dalam PP No. 24 Tahun 1997, yaitu dimasukannya penegasan yang tidak jelas dalam pertauran sebelumnya yaitu pengertian tanah, asas dan tujuan. Dalam hal ini, peraturan pemerintah memberikan kepastian hukum untuk menghimpun dan menyajikan informasi yang lengkap mengenai data fisik dan data yuridis dari tanah yang bersangkutan. Berlakunya peraturan pemerintah ini juga adalah peraturan pelaksana dari UUPA yang baru hingga saat ini. Dalam peraturan ini juga dilakukan penyederhanaan mengenai pengumpulan data penguasaan tanah, sehingga dalam pendaftaran tanah yang dilakukan tidak akan menimbulkan kesalahan yang akan berdampak pada permasalaan yang baru yang merugikan dari pemilik hak atas tanah tersebut.

Dengan beberapa kali dilakukannya perubahan atas dasar hukum pendaftaran tanah tersebut merupakan kepentingan untuk mengelaborasikan peraturan, maka dibuatlah peraturan menteri negara agraria/ Badan Pertanahan Nasional No. 3 Tahun 1997 tentang Ketentuan pelaksana PP No. 24 tahun 1997 yang dijadikan pedoman teknis bagi BPN dalam menyelenggarakan kegiatan pendaftaran tanah yang menjadikan kekuatan BPN dalam menjalankan kewenangannya. Seiring berjalannya waktu, peraturan menteri ini dilakukan perubahan dengan berlakunya Peraturan Kepala Kantor pertanahan Nasional No. 8 Tahun 2012 tentang perubahan atas peraturan menteri Negara Agraria/ Kepala Badan Pertanahan Nasional No. 3 Tahun 1997 dan PP No. 24 Tahun 1997.

Pelaksanaan kegiatan pendaftaran tanah dapat dilakukan dengan pendaftaran tanah untuk pertama kali dan pemeliharaan data pendaftaran tanah seperti yang terdapat didalam PP No. 24 Tahun 1997. Penjelasan yang terdapat dalam peraturan pemerintah tersebut mengatakan bahwa pendafatran tanah untuk pertama kali meliputi pengumpulan dan pengolahan data fisik, pembuktian hak dan pembukuannya, penerbitan sertifikat, penyajian data yuridis, penyimpanan data umum dan dokumen. Sedangkan penjelasan kegiatan pemeliharaan data pendaftaran tanah meliputi komponen antara lain pendaftaran peralihan hak dan pembebanan hak, pendaftaran perubahan data, dan pendaftaran tanah lainnya yang sifatnya pemeliharaan dan pendaftaran. 
Kewenangan Badan Pertanahan Nasional (BPN) selaku lembaga negara yang pertama kali berwenang melakukan kegiatan pendaftaran tanah untuk pemeliharaan data pendafatran tanah. Pada aplikasinya, terutama ditingkat kantor pertanahan yang secara langsung berhubungan dengan masyarakat dalam kegiatan pensertifikatan tanah, terdapat kebijakan-kebijakan yang diambil oleh kepala kantor pertanahan dalam pelaksanaan kegiatan pendaftaran tanah. Hal tersebut disebabkan, dalam pelaksanaan pendaftaran tanah terutama prosedur adminitrasinya terkadang menimbulkan permasalahan baru yang menyebabkan kepala kantor pertanahan harus mengambil jalan tengah dalam menyelesaikan masalah yang ada dengan mendukung kegiatan pendaftaran tanah.

Penjelasan yang berkaitan dengan kesenjangan dalam pendaftaran tanah yang melibatkan kepala kantor pertanahan tersebut dapat menjadi permasalahan yang menimbulkan suatu perbuatan yang tidak akan terselesaikan sampai dengan adanya perubahan dan pembaharuan terhadap peraturan pemerintah dan peraturan lainnya yang membahas mengenai pendaftaran tanah. Riskan sekali membahas mengenai pendaftaran tanah pada era modern seperti sekarang ini, hal ini dikarenakan dalam pencapaian akses dalam melakukan kejahatan semakin mudah dilakukan oleh pejabat yang diberikan kewenangan sebagai kepala dalam pendaftaran tanah. Maka dari itu perlu ditindaklanjuti dalam penekanan bahasa dan istilah dalam peraturan pemerintah yang akan mensejahterakan masyarakat.

\section{Implikasi Hukum Kebijakan Kepala Kantor Pertanahan Dalam Pendaftaran Tanah}

Penjelasan PP No. 24 Tahun 1997 tentang Pendaftaran Tanah dalam pelaksanaan kegiatan pendaftaran tanah terdapat 2 (dua) kegiatan yang menjadi pokok utama dalam pendaftaran tanah. Pertama yaitu kegiatan pendaftaran tanah untuk pertama kali, kegiatan ini dapat dilakukan baik secara sistematik maupun secara sporadik yang dilaksanakan dengan prosedur yang jelas dan tidak bertentangan dengan peraturan yang ada serta tidak berpihak kepada kepentingan kelompok yang menekan pada masyarakat bawah, sehingga kebijakan yang ada tersebut tidak merugikan masyarakat. Kepentingan masyarakat lebih diutamakan dan paling utama dalam pelaksanaan kebijakan, agar kebijakan atau peraturan tepat pada sasaran dan menjadi kontrol yang jelas bagi masyarakat.

Kedua, kegiatan pemeliharaan data pendaftaran tanah, hal ini sangat menegaskan kepada pemilik hak atas tanah untuk melakukan pendaftaran tanah di kantor pertanahan. Pada tataran pelaksanaanya, sangat memungkinkan menimbulkan kondisi tertentu yang berbeda dari peraturan perundang-undangan tentang pendafataran tanah. Kondisi tersebut dapat berupa kebijakan yang diambil kepala kantor pertanahan dalam kegiatan pendaftaran pemeliharaan data pendaftaran tanah.

Pasal 37 ayat (1) PP No. 24 Tahun 1997 menentukan bahwa peralihan hak atas tanah dan hak milik atas satuan rumah susun melalui jual beli tukar menukar, hibah, pemasukan dalam perusahaan dan perbuatan hukum pemindahan hak lainnya, kecuali pemindahan hak melalui lelang hanya dapat didaftarkan jika dapat dibuktikan dengan akta yang dibuat oleh PPAT yang berwenang menurut ketentuan pertauran perundangundangan yang berlaku. Apabila dalam kenyataannya kepala kantor pertanahan secara subjektif mengenyampingkan ketentuan pasal tersebut, sehingga tanpa dibuktikannya akta yang dibuat oleh PPAT peralihan hak atas tanah tersebut dapat didaftarkan. Hal inilah yang menyebabkan peralihan hak atas tanah yang dilakukan tidak sesuai dengan peraturan yang berlaku, secara tidak langsung hal tersebut merupakan perbuatan yang melanggar hukum.

Kepala kantor pertanahan tidak boleh membuat asumsi hukum bahwa dalam keadaan tertentu sebagaimana yang telah ditentukan oleh Menteri, Kepala Kantor Pertanahan dapat mendaftarkan pemindahan hak atas bidang tanah yang dilakukan antara peroranag warga negara indonesia berdasarkan akta yang tidak dibuat oleh PPAT, hal ini sangat bertentangan dengan Pasal 37 yang sudah dijelaskan sebelumnya. Namun pada hakikatnya, bahwa setiap peraturan itu ada pengecualiannya yang dijadikan sebagai dasar dalam penegakan hukum. Tapi pada kenyataannya, hal tersebut digunakan oleh orang-orang atau oknum-oknum tertentu bahkan kepala kantor pertanahan sendiri untuk mengenyampingkan isi Pasal 37 tersebut. Sebenarnya pengecualian tersebut diberlakukan untuk masyarakat yang berada di daerah-daerah terpencil yang sulit untuk mengakses pejabat pembuat akta tanah, biasanya hal ini dilakukan di desa-desa terpencil yang jauh dari keramaian namun tanah yang dimiliki harus mempunyai kekuatan hukum.

Keadaan tertentu yang terdapat didalam peraturan pemerintah No. 24 Tahun 1997 maupun peraturan lainnya tentang pendaftaran tanah, belum mempunyai kriteria yang jelas dan dapat menjadi rujukan sebagai landasan hukum yang kuat. Apabila tidak diperjelas, maka kondisi tersebut sangat menghawatirkan karena akan menimbulkan banyaknya perdebatan dan menimbulkan multitafsir di kalangan penegak hukum dan di 
kalangan masyarakat. Selain itu, kepala kantor pertanahan dapat menggunakan keadaan tertentu sebagai alat untuk mengenyampingkan isi Pasal 37 PP. No. 24 Tahun 1997 tentang Pendaftaran Tanah tersebut.

Kepala kantor pertanahan sebagai pejabat yang diberi wewenang dalam melakukan pendaftaran peralihak hak milik atas tanah seharusnya memberikan dukungan yang positif agar masyarakat menjalankan amanat yang disampaikan oleh perturan perundang-undangan. Sehingga dalam pelaksanaan masih banyak sekali kepala kantor pertanahan melakukan penyelewengan atas dasar jabatan yang dimiliki. Jabatan yang dimiliki sangat memungkinkan sekali terjadi pergeseran paradigma dan nilai-nilai pancasila yang hilang dalam tubuh seorang kepala kantor pertanahan. Kepentingan politik dan kapitalisme penguasa yang menjadikan rusaknya generasi dan menimbulkan banyak salah paham terhadap masyarakat mengenai pertanahan dan menimbulkan persoalan-persoalan terkait peralihan hak milik atas bidang tanah.

Berdasarkan dari penjelasan di atas, kebijakan kepala kantor pertanahan tersebut jika dihadapakan dengan ketentuan Pasal 37 PP N. 24 Tahun 1997 tentang Pendaftaran Tanah, maka Implikasi yang ditimbulkan berupa: Kebijakan mendaftarkan pemindahan hak atas bidang tanah yang dilakukan tidak sah. Artinya apabila tidak sah maka yang berhak mempertanggungjawabkan hal tersebut adalah kepala kantor pertanahan yang sudah melakukan penyelewengan terhadap ketentuan yang ada. Implikasi tersebut berlaku sepanjang kepala kantor pertanahan dengan terang-terangan melakukan dan mendaftarkan pemindahan hak atas sebidang tanah di daerah perkotaan yang sudah pasti tidak termasuk kategori terpencil sebagaimana yanag terdapat dalam ketentuan Pasal 37 PP No. 24 Tahun 1997 tentang Pendafataran Tanah. Tanah terpencil atau desa terpencil yang jauh dari akses membuat adanya pengecualian yang dapat diberikan, sehingga dalam pengecualian harus memberikan atau memberlakukan syarat dan ketentuan yang ada.

Kebijakan yang dilakukan oleh kepala kantor pertanahan tentang mendaftar pemindahan hak atas bidang tanah yang merupakan hak milik dapat dipastikan tidak bertentangan dengan dengan ketentuan Pasal 37 PP. No.24 Tahun 1997 tentang Pendaftaran Tanah sepanjang kebijakan yang dilakukan oleh kepala kantor pertanahan hanya mendaftar pemindahan hak atas bidang tanah dan hak milik di daerah terpencil saja, dan tidak mencampurkan unsur kepentingan tertentu yang akan merusak ketentuan Pasal 37 PP No. 24 Tahun 1997 tentang Pendaftaran Tanah.

Namun sebenarrnya, akan lebih baik lagi jika ketentuan Pasal 37 PP No. 24 Tahun 1997 tersebut diperinci lebih jelas agar tidak terjadi penyalahgunaan maupun kesalahan pengambilan kebijakan oleh kepala kantor pertanahan. Agar ukurannya menjadi jelas dan lebih menjamin kepastian hukum dan keadilan hukum. Karena apabila hal tersebut terjadi yang dirugikan pasti masyarakat yang berada dibawah dan tidak mengerti akan pembelaan terhadap hak yang dimiliki.

Dengan demikian permasalahan implikasi terhadap kebijakan yang dilakukan oleh kepala kantor pertanahan sangat merugikan dan menyalahgunakan aturan dan ketentuan yang berlaku. Pasal 37 ini harus dilakukan perbaikan agar sesuai dengan harapan yang didambakan oleh masyarakat banyak dan menjadikan pedoman yang tidak dapat disalahgunakan oleh kepala kantor pertanahan yang menyelewengkan wewenangnya tersebut. Penyelewengan wewenang yang dilakukan oleh kepala kantor pertanahan dan memanfaatkan keadaan bukan hanya satu masyarakat yang terkena imbasanya. Namun banyak dan ribuan masyarakat yang kurang mampu dan buta dengan hukum yang merasakan imbasnya, maka dari itu perlu untuk diperbaiki dan ditinjau kembali isi dari Pasal 37 PP No. 24 Tahun 1997 tentang Pendaftaran Tanah.

\section{Kesimpulan}

Berdasarkan penjelasan yang dikemukan di atas, maka dapat disimpulkan dalam penelitian ini bahwa pengaturan pendaftaran tanah yang terdapat dalam ketentuan peraturan perundang-undangan yang berlaku di Negara Indonesia secara filosofi berlandaskan pada ketentuan Pasal 33 ayat (3) Undang-Undang Dasar 1945 yang kemudian menjadi dasar pembentukan Undang-Undang Nomor 5 Tahun 1960 tentang Peraturan Dasar Pokok-Pokok Agraria. Pendaftaran tanah secara khusus pertama kali diatur dalam Peraturan Pemerintah Nomor 10 Tahun 1961 tentang Pendaftaran Tanah yang sekarang ini sudah dicabut dengan menjadikan tidak berlaku karena keluarnya Peraturan Pemerintah Nomor 24 Tahun 1997 tentanag Pendaftaran Tanah. Pengaturan pendaftaran tanah kemudian dielaborasikan dalam peraturan menteri negara agraria/BPN Nomor 3 Tahun 1997 tentang Ketentuan Pelaksanaan Peraturan Pemerintah Nomor 24 Tahun 1997 tentang Pendaftaran Tanah yang telah mengalami beberapa kali perubahan yang terakhir keluarnya dan diberlakukannya Peraturan Kepala Badan Pertanahan Nasional Nomor 8 Tahun 2012 tentang Perubahan Atas Peraturan Menteri Agraria/BPN.

Kepala kantor pertanahan dalam pendaftaran tanah yang muncul pada saat pemeliharaan data pendaftaran tanah dapat berupa mendaftarkan pemindahan hak atas bidang tanah hak milik dengan 
memeperhatikan kententuan Pasal 37 tersebut. Kebijakan kepala kantor pertanahan tesebut dihadapkan dengan ketentuan Pasal 37 akan berimplikasi sebagai berikut: kebijakan mendaftar pemindahan hak atas bidang tanah hak milik yang dilakukan kepala kantor petanahan bertentangan dengan ketentuan Pasal 37 PP 24/1997 sehingga pemindahan hak yang dilakukan tidak sah. Implikasi berlaku sepanjang kepala kantor pertanahan dengan terang-terang mendaftarkan pemindahan hak atas bidang tanah hak milik di daerah perkotaan yang sudah pasti tidak termasuk kategori daerah terpencil sebagaimna dimaksud dalam Pasal 37 tersebut.

Oleh karenanya perlu dilakukan perubahan Pasal 37 yang mengatur keadan tertentu, karena jika tidak dilakukan demikian maka kesalahan dan pelanggaran akan selalu terjadi dan membuat peraturan tersebut tidak berfungsi dengan semestinya. Namun akan lebih baik jika keadaan tertentu yang diamksud diperinci dalam batang tubuh sehingga tidak menimbulkan multi tafsir/ interpretasi yang dapat menjadi celah terjadinya pelanggaran dan penyelahgunaan wewenang sehingga berpotensi merugikan masyarakat. Perubahan perlu dilakukan untuk menjamin kepastian hukum dan keadilan hukum. Kemudian dalam membuat kebijakan sebaiknya kepala kantor pertanahan memberikan penjelasan kepada masyarakat, sehingga tidak menimbulkan kesalahpahaman dalam kegiatan pendaftaran tanah.

\section{DAFTAR PUSTAKA}

\section{A. Buku}

Ermit, H. (2004). Cara Memperoleh Sertipikat Tanah Hak Milik, Tanah Negara, dan Tanah Pemda, Teori Praktek Pendaftaran Tanah di Indonesia. Bandung: Mandar Maju.

Marzuki, Peter Mahmud. (2013). Penelitian Hukum. Jakarta: Kencana.

A.P Perlindungan. (1985). Pendaftaran dan Konvensi Hak-Hak Atas Tanah Menurut UUPA. Bandung: Alumni.

\section{B. Jurnal dan Artikel}

Haris Yonata Permahan Sibuca, “Arti Penting Pendaftaran Tanah untuk Pertama Kali”, Negara Hukum, Vol. 2 No. 2, (2011).

Elita Rahmi, "Eksistensi Hak Pengelolaan atas Tanah (HPL) dan Realitas Pembangunan Indonesia", Dinamika Hukum, Vol. 10 No. 3, (2010).

Ana Silviana, "Kajian Tentang Kesadaran Hukum Masyarakat Dalam Melaksanakan Pendaftaran Tanah", Pandecta, Vol. 7 No. 1, (2012).

\section{Peraturan Perundang-Undang}

Undang-Undang Dasar Negara Republik Indonesia 1945.

Undang-Undang Nomor 5 Tahun 1960 tentang Peraturan dasar Pokok-Pokok Agraria

Peraturan Pemerintah Nomor 24 Tahun 1997 tentang Pendaftaran Tanah.

Peraturan Menteri Negara Agraria/ Kepala BPN No. 3 tahun 1997 ekmudian dirubah dengan Peraturan Meteri Negara Agraria/ Kepala BPN No. 8 Tahun 2012 tentanag Ketentuan Pelaksana PP No. 24/1997 tentanag Pendaftaran Tanah. 
